\title{
Menimbang Kompetensi Calon Guru Matematika dalam Penyelenggaraan Pembelajaran Daring
}

\section{Efron Manik}

Pendidikan Matematika, Universitas HKBP Nommensen, Medan, Indonesia; efmanik@gmail.com

Info Artikel: Dikirim: 6 Februari 2021; Direvisi: 5 Maret 2021; Diterima: 11 Maret 2021

Cara sitasi: Manik, E. (2021). Menimbang Kompetensi Calon Guru Matematika dalam Penyelenggaraan Pembelajaran Daring. JNPM (Jurnal Nasional Pendidikan Matematika) 5(1), 13-22.

\begin{abstract}
Abstrak. Covid-19 mengubah proses pembelajaran di seluruh dunia, termasuk Indonesia. Mulai bulan Maret 2020, banyak sekolah menyelenggarakan proses pembelajaran secara daring. Kegiatan ini membuat guru harus menyesuaikan diri dengan situasi yang tidak pernah terjadi ini. Kurikum bagi mahasiswa calon guru tidak pernah dirancang dengan kompetensi untuk pembelajaran daring. Pembelajaran daring menggunakan banyak media pembelajaran berbentuk video yang dibagikan langsung kepada siswa berbentuk file atau diupload ke youtube. Tujuan dari penelitian ini adalah untuk mengetahui hubungan antara kompetensi calon guru matematika dengan tingkat keberhasilan mereka dalam menyelenggarakan pembelajaran daring. Hasil analisa data penelitian menunjukkan bahwa ada hubungan antara kompetensi calon guru matematika dengan tingkat keberhasilan mereka dalam menyelenggarakan pembelajaran daring dengan taraf siginfikansi $5 \%$. Tetapi jika plot data variabel bebas dan variabel terikat dicermati maka hubungan ini hanya dipengaruhi oleh beberapa mahasiswa saja. Artinya jika mahasiswa tersebut dikeluarkan dari data maka kesimpulan akan berkata sebaliknya. Sehingga penelitian lanjutan perlu diketahui untk mengetahui kejadian yang lebih cermat.
\end{abstract}

Kata Kunci: kurikulum, video, kompetensi, guru, daring.

Abstract. Covid-19 is changing the learning process around the world, including Indonesia. Starting in March 2020, many schools hold online learning processes. This activity makes the teacher have to adjust to this situation. Curriculum for student teacher candidates has never been designed with competencies for online learning. Online learning uses many learning media in the form of videos which are distributed directly to students in the form of files or uploaded to youtube. The purpose of this study was to determine whether there is a relationship between the competence of mathematics teacher candidates and their success rate in organizing online learning. The results of the analysis of the research data show that there is a relationship between the competence of prospective mathematics teachers with their success rate in organizing online learning with a significance level of $5 \%$. But if the data plot of the independent variable and the dependent variable is considered, this relationship is only affected by a few students. This means that if the student is excluded from the data, the conclusion will say the opposite. So that further research needs to be known to find out more accurate incidents.

Keywords: curriculum, videos, competencies, teachers, online. 


\section{Pendahuluan}

Covid-19 mengubah tatanan dunia yang tidak pernah terpikirkan oleh siapapun. Tidak ada negara di seluruh dunia yang luput dari keganasan pandemik ini. Memakai masker, rajin mencuci tangan, dan menjaga jarak satu sama lain menjadi protokol kesehatan yang harus dilakukan setiap orang. Situasi ini juga sangat mempengaruhi dunia kerja yang diharapkan sebanyak mungkin tenaga kerjanya harus bekerja dari rumah. Demikian juga di sekolah, proses pembelajaran dilakukann secara daring.

Pemilihan media pembebelajaran sangat menentukan keberhasilan proses pembelajaran daring. Media pembelajaran harus terintegrasi dengan model pembelajaran yang dipilih (Manik, 2020). Media dapat digunakan untuk menyalurkan konsep pemikiran dan pesan dengan lebih mudah dipahami oleh peserta didik (Manik \& Panjaitan, 2015). Media yang buruk akan membuat pemahaman siswa tentang konsep matematika menjadi rendah (Setiyani, Putri, Ferdianto, \& Fauji Setiyani, 2020).

Banyak penelitian menyatakan bahwa media pembelajaran membuat proses pembelajaran lebih menarik dan dapat meningkatkan hasi pembelajaran. Kreativitas peserta didik dapat ditingkatkan dengan menggunakan media pembelajaran (Ummah, Inam, \& Azmi, 2019). Media pembelajaran berbasis teori belajar Bruner yang disesuaikan dengan budaya lokal mampu meningkatkan pemahaman konsep pada materi pelajaran relasi dan fungsi (Handayani, Ardana, \& Sudiarta, 2020). Media pembelajaran berbentuk Inspring Suite 8 yang didukung oleh fitur visualisasi 3D dapat meningkatkan hasil belajar pada topik geometri (Nurwijayanti, Budiyono, \& Fitriana, 2019) bahkan media seperti ini dapat dikembangakan menjadi 4D (Ferdianto \& Setiyani, 2018). Media pembelajaran menggunakan aplikasi komputer dalam bentuk Excel dapat mempermudah pembelajaran pada topik statistika dengan pendekatan pendidikan matematika realistik (PMR) (Sari, 2017). Media pembelajaran interaktif dengan model pembelajaran Reciprocal Teaching dapat meningkatkan kemampuan komunikasi peserta didik (Mahadewi, Ardana, \& Mertasari, 2020).

Media pembelajaran dapat juga dibuat dan disebarluaskan dengan menggunakan teknologi informasi. Flipbook yang mirip seperti buku animasi, video yang diiringi dengan musik lebih baik dari dari media pembelajaran bukan flipbook (Andini, Budiyono, \& Fitriana, 2018). Game dalam bentuk media pembelajaran yang dikemas dan dijalankan di android dapat membuat proses pembelajaran lebih praktis (Pramuditya, Noto, \& Purwono, 2018). Video animasi media pembelajaran juga dapat dibuat 
dengan software macromedia flash untuk dapat membantu pemahaman peserta didik terhadap suatu konsep matematika (Kania, 2020).

Salah satu media pembelajaran yang banyak digunakan dalam proses pembelajaran daring adalah video pembelajaran. File video diberikan kepada siswa/i secara langsung atau video tersebut diletakkan di Youtube yang ditonton siswa/i secara daring. Pengembangan video pembelajaran harus mengikuti 6 tahapan pengembangan (Cahyono, Pratama, Arga, \& Rani, 2020), yaitu: (1) Analisa masalah dan kebutuhan, (2) Merancang tampilan video, (3) Mengumpulkan bahan-bahan yang dibutuhkan dalam pembuatan video, (4) Menggabungkan semua bahan-bahan yang sudah dikumpulkan, (5) Menguji kelayakan video yang dibuat, dan (6) Mendistribusikan file video atau meng-upload di Youtube. Konten Pendidikan yang positip di Youtube masih sangat kurang dan membutuhkan kontribusi banyak pihak. Keadaan ini masih menjadi masalah dan sekaligus potensi yang layak dikembangkan (Rahmawan, Mahameruaji, \& Preciosa, 2018).

Ada lebih dari satu miliar video pembelajaran di Youtube ditonton setiap hari di seluruh dunia. Aliran video Pendidikan dapat dikelompokkan dalan 3 kelompok besar, yaitu: (1) gabungan hiburan dan pendidikan, (2) Pendidikan berbasis kurikulum, dan (3) Pendidikan berbasis ketrampilan. Youtube dapat menjadi sumber belajar yang potensial (Suwarno, 2017). Hal ini dapat dilihat selama pembelajaran daring. Banyak video pembelajaran yang dibuat guru diupload di Youtube dan murid-muridnya diminta untuk menonton video tersebut.

Dalam kurikulum calon guru matematika di perguruan tinggi, tidak ada mata kuliah yang khusus mendalami video pembelajaran sesuai aliran di Youtube. Pada hal dalam pembelajaran daring, banyak proses pembelajaran daring menggunakan video pembelajaran sebagai media pembelajaran. Guru di sekolah belum terbiasa dengan keadaan proses pembelajaran tersebut. Karena mereka saat kuliah tidak pernah dipersiapkan untuk menghadapi situasi seperti ini. Perguruan tinggi yang menghasilkan guru selama ini belum pernah menetapkan kompetensi lulusan dan profil lulusannya untuk mampu menjadi guru dalam proses pembelajaran daring. Sehingga kurikulum di Lembaga Pendidikan dan Tenaga Kependidikan (LPTK) tidak diperuntukkan untuk situasi pandemik. Karena salah satu yang dianalisa dalam penyusunan kurikulum adalah kompetensi lulusan atau profil lulusan yang akan menjadi unsur yang sangat dipertimbangkan dalam menyusun tujuan Pendidikan. Tujuan pendidikan akan dijabarkan ke dalam beberapa 
mata kuliah setiap semester. Selanjutnya kompetensi yang diharapkan pada mata kuliah tersebut dituliskan dalam bentuk bahan ajar yang akan dipelajari dalam perkuliahan (Suteja, 2017).

Mahasiswa Program Studi Sarjana Pendidikan Matematika Fakultas Keguruan dan Ilmu Pendidikan Universitas HKBP Nommensen masih menggunakan kurikulum berbasis Kerangka Kualifikasi Nasional Indonesia (KKNI). Profil lulusan dari program studi ini adalah guru matematika, peneliti bidang pendidikan matematika, edupreneur pendidikan, dan penulis dalam bidang matematika (Panjaitan, Saragih, \& Tampubolon, 2016). Sehingga semua mata kuliah yang disusun akan berdasarkan profil lulusan tersebut.

Profil lulusan Program Studi Pendidikan Matematika Universitas HKBP Nommensen tidak mempersiapkan mahasiswa untuk menjadi guru daring. Karena program studi tidak menduga akan terjadi pandemi sedasyat ini pada saat penyususnan kurukulum berbasis KKNI. Sehingga untuk mengetahui kemampuan kurikulum KKNI menghadapi tantangan jaman maka tujuan penelitian ini adalah mengetahui ada hubungan antara kompetensi calon guru matematika dengan tingkat keberhasilan mereka dalam menyelenggarakan pembelajaran daring.

\section{Metode}

Penelitian ini dilakukan di Program Studi Pendidikan Matematika Universitas HKBP Nommensen mulai pada bulan Maret 2020 saat perkuliahan daring di kampus dan proses pembelajaran daring di sekolah dimulai. Sedangkan sampel adalah mahasiswa yang sudah menyelesaikan mata kuliah Praktik Pengalaman Lapangan (PPL) dan hampir menyelesaikan semua mata kuliah.

Variabel dari penelitian ini terdiri dari variabel bebas yaitu kompetensi calon guru matematika yang disimbolkan dengan variabel $X$. Kompetensi ini diukur dari transkrip nilai yang diperoleh mahasiswa setelah menyelesaikan perkuliahan. Tingkat kompetensi calon guru matematika diukur dengan indeks prestasi kumulatif (IPK) dari transkrip nilai calon guru. IPK menggambarkan kompetensi mahasiswa yang dihasilkan oleh kurikulum perguruan tinggi. Mahasiswa dengan nilai IPK yang tinggi dianggap memiliki tingkat kompetensi yang tinggi sedangkan nilai IPK yang rendah dianggap kurang menguasai kompetensi. IPK yang diteliti atau dikumpulkan hanya IPK dari 45 orang mahasiswa yang termasuk dalam sampel penelitian. 
Variabel terikat yaitu tingkat keberhasilan calon guru matematika dalam menyelenggarakan pembelajan daring yang dinotasikan dengan variabel Y. Media pembelajaran yang sering digunakan dalam pembelajaran daring adalah video pembelajaran yang dibuat mahasiswa dan diupload di Youtube. Tingkat keberhasilan pembelajaran daring diukur dengan jumlah tayang video pembelajaran yang dibuat oleh mahasiswa setelah url video youtube tersebut diposting beberapa hari di grup facebook fakultas.

Data dari variabel bebas dan variabel terikat akan dikumpulkan dan diolah dengan taraf signifikansi $\alpha=5 \%$. Pertama, rata-rata dan standar deviasi dari data dihitung. Setelah itu data variabel bebas dan data variabel terikat diuji kenormalannya. Hubungan antara variabel bebas dan variabel terikat dihitung dan diuji dengan menggunakan regresi jika kedua data berdistribusi normal, dan rumus keoefisien korelasi pangkat jika tidak kedua data berdistribusi normal (Sujana, 1975). Akhirnya diputuskan apakah ada hubungan antara kompetensi calon guru matematika dengan tingkat keberhasilan mereka dalam menyelenggarakan pembelajaran daring dan seberapa besar hubungan tersebut.

\section{Hasil dan Pembahasan}

Sampel video pembelajaran mahasiswa yang sudah selesai diupload di Youtube, url-nya dibagikan di grup facebook fakultas dengan pesan supaya mahasiswa lain membagikannya di media sosial masing-masing. Setelah satu minggu diposting, jumlah tayang video tersebut dicatat sebagai data variabel terikat Y, yaitu: tingkat keberhasilan calon guru matematika dalam menyelenggarakan pembelajan daring. Pemilihan satu minggu didasari oleh pertimbangan dan asumsi bahwa jumlah jam aktivitas orang di media sosial akan berulang untuk setiap minggunya.

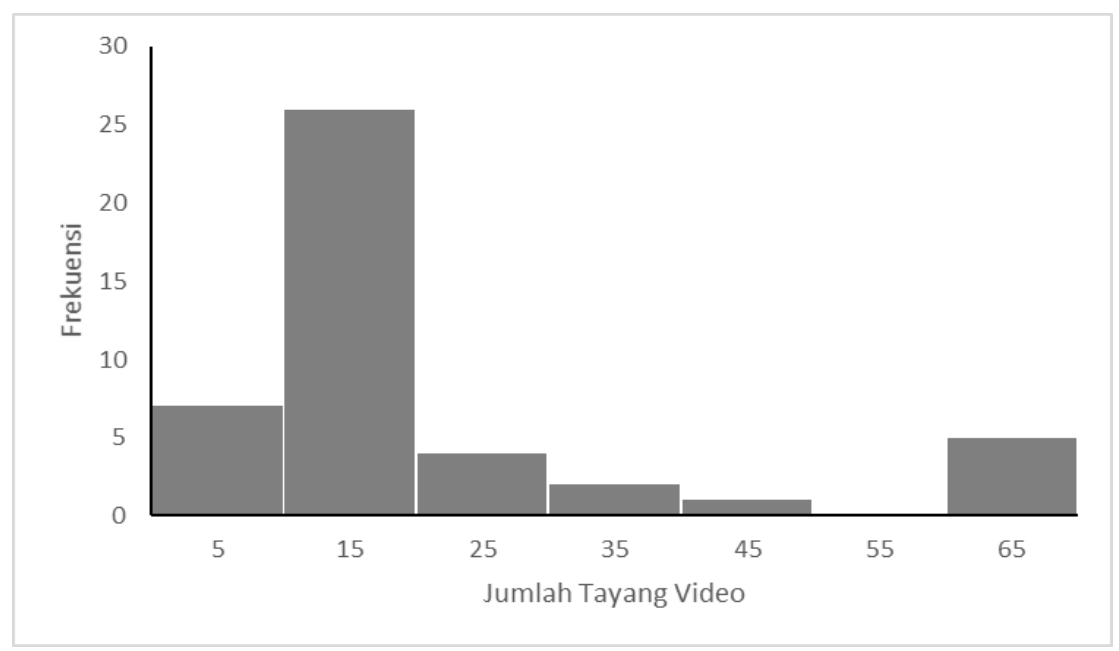

Gambar 1. Data Jumlah Tayang Video Pembelajaran di Youtube 
Gambar 1 menunjukan diagram batang dari data Y. Nilai minimum dari Y adalah 6, artinya video Youtube tersebut ditonton sebanyak 6 kali selama satu minggu setelah URL video tersebut diposting di grup Facebook Fakultas. Nilai maksimum dari Y adalah 66, yaitu video Youtube tersebut ditonton sebanyak 66 kali selama satu minggu setelah URL diposting di grup Facebook Fakultas. Dapat disimpulkan jumlah tayangan video yang paling banyak berada disekitar 15 tayangan. Rata-rata dari data Y adalah 20,22 dan simpangan bakunya adalah 17,13. Dengan memperhatikan diagram batang dari data pada Gambar 1, distribusi ini berbedah sangat jauh dari distribusi normal. Data ini diperkuat dengan pengujian data dengan menggunakan uji Lilliefors (Sujana, 1975). Dari perhitungan diperoleh $\mathrm{L}_{0}=0,2875$. Nilai ini dibandingkan dengan nilai L tabel sebesar 0,1321 untuk $\alpha=5 \%$ dan banyak sampel $n=45$ orang. Karena Lo lebih besar dari L tabel maka disimpulkan bahwa data Y (tingkat keberhasilan calon guru matematika dalam menyelenggarakan pembelajan daring) berdistribusi tidak normal.

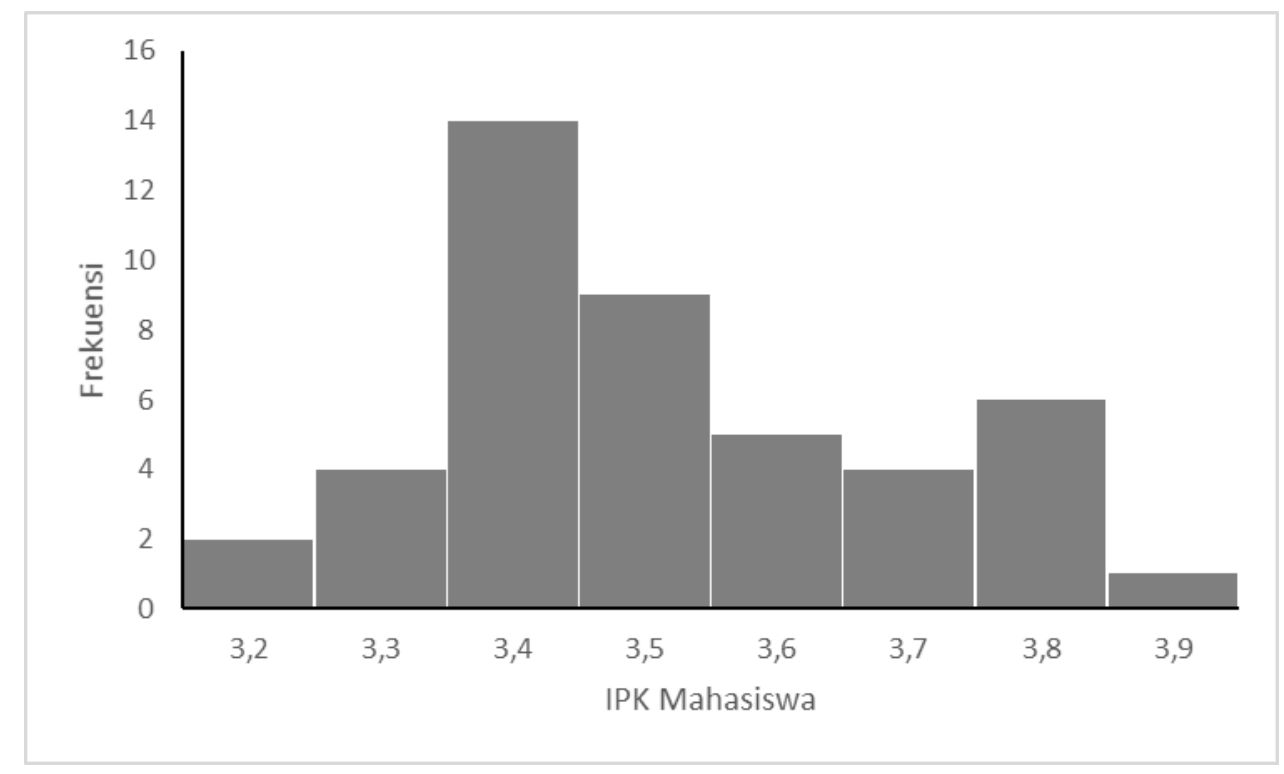

Gambar 2. Diagram Batang Data IPK Mahasiswa

Gambar 2 menunjukkan diagram batang. IPK yang paling kecil adalah 3,25 sedangkan IPK yang paling tinggi adalah 3,90. IPK mahasiswa yang paling banyak berada di sekitar 3,40. Rata-rata dari data $X$ adalah 3,56 dan standar deviasinya adalah 0,17. Jika melihat diagram batang pada Gambar 2, data ini kelihatan mirip sedikit dengan kurva data berdistribusi normal. Tetapi untuk memastikan kenormalan suatu data, uji Lilliefors (Sujana, 1975) akan digunakan untuk memastikannya. Dari perhitungan diperoleh $\mathrm{L}_{0}=0,1413$ dan nilai ini akan dibandingkan nilai L tabel sama dengan 0,1321. Dengan mengkonsultasikan kedua nilai ini disimpulkan bahwa data $X$ (tingkat kompetensi calon guru matematika) tidak berdistribusi tidak normal. 
Gambar 3 merupakan gabungan data $X$ dan data Y. Penyebaran data menunjukkan bahwa kebanyakan mahasiswa menghasilkan jumlah tayangan video yang tidak berbeda walaupun IPK mereka berbeda. Penyajian data $X$ dan $Y$ secara Bersama-sama juga menunjukkan bahwa tidak ada mahasiswa yang IPK-nya kurang dari 3,50 mempunyai tayangan video lebih dari 30 kali tayangan. Tetapi beberapa mahasiswa yang IPK-nya lebih dari 3,5 mempunyai jumlah tanyangan video yang lebih banyak secara signifikan dari teman-temanya yang lain. Datum dari beberapa orang ini akan mempengaruhi hubungan data X dan Y secara keseluruhan.

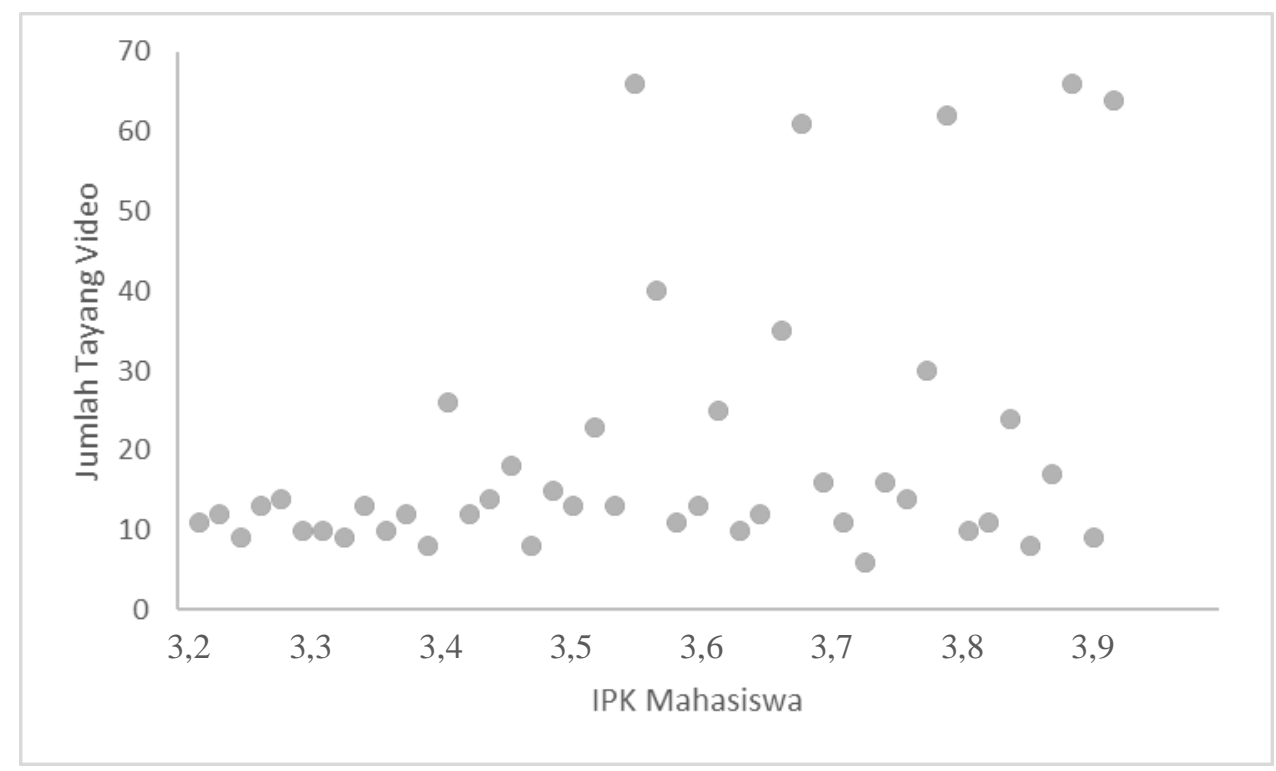

Gambar 3. Hubungan antara IPK Mahasiswa dan Jumlah Yayang Video

Karena kedua data X dan Y berdistribusi tidak normal, maka uji hubungan yang akan digunakan adalah Koefisien Korelasi Pangkat (Sujana, 1975). Dari perhitungan diperoleh nilai koefisien korelasi pangkat $r^{\prime}$ sama dengan 0,3068. Berdasarkan nilai ini diperoleh $Z$ hitung, $Z$, sama dengan 2,0350. Untuk $\alpha=5 \%$ diperoleh $Z$ tabel, $Z_{t}$, sama dengan 1,96. Karena $Z_{h}$ lebih besar dari $Z_{t}$ maka disimpulkan Tolak $\mathrm{H}_{0}$ atau Terima $\mathrm{H}_{\mathrm{A}}$, yaitu: ada hubungan antara variabel $X$ dan $Y$ secara signifikan. Keputusannya adalah ada hubungan antara IPK mahasiswa dengan jumlah tayangan video yang dibuatnya. Jika kita melihat kembali pada pembahasan maka dapat juga disebutkan bahwa ada hubungan yang signifikan antara kompetensi calon guru matematika dengan tingkat keberhasilan mereka dalam menyelenggarakan pembelajan daring. Nilai $r^{\prime}$ sama dengan 0,3068 memberikan gambaran kepada kita bahwa kategori hubungan antara 
kompetensi calon guru matematika dengan tingkat keberhasilan mereka dalam pembelajan daring adalah sedang.

Indeks Prestasi mahasiswa (IPK) program studi pendidikan matematika Universitas HKBP Nommensen adalah ukuran kemampuan mahasiswa menguasai kurikulum berbasis KKNI. Guru yang mampu menyelenggarakan pembelajaran daring tidak termasuk dalam profil lulusan yang diharapkan dari kurikulum (Panjaitan, Saragih, \& Tampubolon, 2016). Mata kuliah program studi yang paling berhubungan dengan penyelenggaraan daring adalah hanya mata kuliah media pembelajaran. Sehingga hubungan dengan taraf sedang antara kompetensi calon guru matematika dengan tingkat keberhasilan mereka dalam pembelajan daring merupakan pencapaian yang wajar.

Video pembelajaran yang baik dan efektif harus dikembangkan berdasarkan model ASSURE (Purwanti, 2015). Penyempurnaan video perlu dilakukan selama ujicoba sebelum digunakan dalam pembelajaran. Video pembelajaran dalam penelitian ini tidak mengikuti prosedur pembuatan video dengan model ASSURE karena penggunaan video pembelajaran yang sangat mendesak oleh Covid-19. Sehingga korelasi dengan tingkat sedang yang diperoleh dalam penelitian ini dapat dipahami.

\section{Simpulan}

Beberapa kesimpulan dapat ditarik, antara lain: ada hubungan yang signifikan antara kompetensi calon guru matematika dengan tingkat keberhasilan mereka dalam menyelenggarakan pembelajan daring. Hubungan ini sangat dipengaruhi oleh hanya beberapa orang mahasiswa yang IPK-nya tinggi dan jumlah tayangan video pembelajarn dibuatnya di Youtube juga tinggi. Penelitian lanjutan perlu dilakukan untuk melihat faktor penyebah jumlah tayangan yang tinggi dari beberapa orang mahasiswa dalam penelitian ini. Untuk pemangku kepentingan, program studi pendidikan matematika harus memperbaiki kurikulumnya untuk mempersiapakan kemampuan mahasiswa dalam pembelajaran daring.

\section{Ucapan Terima Kasih}

Terima kasih kepada Universitas HKBP Nommensen yang mendanai penelitian ini dan rekan-rekan dosen yang selalu memberikan masukan mulai dari proposal sampai pada saat diskusi hasil dari penelitian ini.

\section{Daftar Pustaka}

Andini, S., Budiyono, \& Fitriana, L. (2018). Developing flipbook multimedia: The 
achievement of informal deductive thinking level. Journal on Mathematics Education, 9(2), 227-238. https://doi.org/10.22342/jme.9.2.5396.227-238

Cahyono, D., Pratama, A., Arga, H., \& Rani, D. (2020). Pengembangan Video Pembelajaran untuk Meningkatkan Hasil Belajar pada Mata Pelajaran Teknologi Jaringan Berbasis Luas ( WAN ) Kelas XI di SMK Negeri 1 Kempas. Journal of Informatics Education, 3(1), 52-61 https://doi.org/10.31331/joined.v3i1.1075.

Ferdianto, F., \& Setiyani, S. (2018). Pengembangan Bahan Ajar Media Pembelajaran Berbasis Kearifan Lokal Mahasiswa Pendidikan Matematika. JNPM (Jurnal Nasional Pendidikan Matematika), 2(1), 37-47. https://doi.org/10.33603/jnpm.v2i1.781

Handayani, N. W. P., Ardana, I. M., \& Sudiarta, I. G. P. (2020). Media Pembelajaran Berbasis Model Bruner, Budaya Lokal, dan Scaffolding untuk Meningkatkan Pemahaman Konsep Relasi dan Fungsi. JNPM (Jurnal Nasional Pendidikan Matematika), 4(2), 221-236. https://doi.org/10.33603/jnpm.v4i2.3235

Kania, N. (2020). Aplikasi Macromedia Flash untuk Meningkatkan Pemahaman Konsep Matematika Siswa. JNPM (Jurnal Nasional Pendidikan Matematika), 4(1), 96-109. https://doi.org/10.33603/jnpm.v4i1.2872

Mahadewi, N. K. N., Ardana, I. M., \& Mertasari, N. M. S. (2020). Kemampuan Komunikasi Matematis Melalui Model Reciprocal Teaching Berbantuan Media Interaktif. JNPM (Jurnal Nasional Pendidikan Matematika), 4(2), 221-236. https://doi.org/10.33603/jnpm.v4i2.3606

Manik, E. (2020). Learning With Higher Order Thinking Skills for Basic Statistics Subject. 488(Aisteel), 224-230. https://doi.org/10.2991/assehr.k.201124.048

Manik, E., \& Panjaitan, S. (2015). Pembuatan Media Pembelajaran Interaktif Dengan Menggunakan Visual Basic. JURNAL Suluh Pendidikan, 2(2), 77-89.

Nurwijayanti, A., Budiyono, \& Fitriana, L. (2019). Combining google sketchup and ispring suite 8: A breakthrough to develop geometry learning media. Journal on Mathematics Education, 10(1), 103-115. https://doi.org/10.22342/jme.10.1.5380.103-116

Panjaitan, B., Saragih, E. I. L., \& Tampubolon, E. H. M. (2016). Pengembangan Perangkat Pembelajaran Berorientasi Kkni Meningkatkan Kompetensi Pedagogik Calon Guru. In U. H. Nommensen (Ed.), Seminar Nasional Hasil Penelitian dan Pengabdian Kepada Masyarakat (p. 58). LPPM Press.

Pramuditya, S. A., Noto, M. S., \& Purwono, H. (2018). Desain Game Edukasi Berbasis Android pada Materi Logika Matematika. JNPM (Jurnal Nasional Pendidikan Matematika), 2(2), 165-179. https://doi.org/10.33603/jnpm.v2i2.919

Purwanti, B. (2015). Pengembangan Media Video Pembelajaran Matematika dengan Model Assure. Jurnal Kebijakan dan Pengembangan Pendidikan, 3(1), 42-47. http://ejournal.umm.ac.id/index.php/jmkpp/article/view/2194

Rahmawan, D., Mahameruaji, J. N., \& Preciosa Alnashava, J. (2018). The Potential of Youtube As Educational Media for Young People (Potensi Youtube Sebagai Media Edukasi Bagi Anak Muda). Edulib, 8(1), 81-98. https://doi.org/10.17509/edulib.v8i1.11267

Sari, S. K. (2017). Pengembangan Desain Pembelajaran Statistika Berbasis IT Menggunakan Pendekatan Realistic Mathematics Education untuk Kelas VIII SMP. JNPM (Jurnal Nasional Pendidikan Matematika), 1(2), 290-304. https://doi.org/10.33603/jnpm.v1i2.495

Setiyani, Putri, D. P., Ferdianto, F., \& Fauji, S. H. (2020). Designing a digital teaching module based on mathematical communication in relation and function. Journal on Mathematics Education, 11(2), 223-236. https://doi.org/10.22342/jme.11.2.7320.223-236

Sujana. (1975). Metode Statistika. Bandung: Tarsito.

Suteja, J. (2017). Model-Model Pembelajaran dalam Kurikulum Berbasis Kompetensi KKNI di Perguruan Tinggi. Jurnal Edueksos, 6(1), 81-100. DOI: 10.24235/edueksos.v6i1.1412 
Suwarno, M. (2017). Potensi Youtube Sebagai Sumber Belajar Matematika. Pi: Mathematics Education Journal, 1(1), 1-7. https://doi.org/10.21067/pmej.v1i1.1989

Ummah, S. K., Inam, A., \& Azmi, R. D. (2019). Creating manipulatives: Improving students' creativity through project-based learning. Journal on Mathematics Education, 10(1), 93102. https://doi.org/10.22342/jme.10.1.5093.93-102 